\title{
Classifying Hydroceles of the Pelvis and Groin: An Overview of Etiology, Secondary Complications, Evaluation, and Management
}

\author{
Gautam Dagur $^{\mathrm{a}} \quad$ Jason Gandhi ${ }^{\mathrm{a}} \quad$ Yiji Suh $^{\mathrm{a}} \quad$ Steven Weissbart ${ }^{\mathrm{b}, \mathrm{c}}$ \\ Yefim R. Sheynkin ${ }^{b} \quad$ Noel L. Smith ${ }^{d} \quad$ Gargi Joshi $^{a} \quad$ Sardar Ali Khan ${ }^{a, b}$ \\ ${ }^{a}$ Department of Physiology and Biophysics; ${ }^{b}$ Department of Urology; and ' Women's Pelvic Health \& Continence Center, Stony

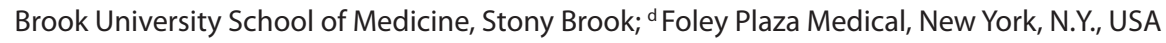

\author{
Key Words \\ Hydrocele $\cdot$ Scrotal pain $\cdot$ Scrotal swelling $\cdot$ Incontinence $•$ \\ Sexual dysfunction $\cdot$ Hernia $\cdot$ Infection of hydrocele $\cdot$ \\ Infertility • Cystic masses
}

\begin{abstract}
Introduction: A hydrocele is defined as the pathological buildup of serous fluid in the pelvis and groin due to various etiologies such as diseases or trauma. It has distinct clinical manifestations, particularly discomfort and psychosocial distress. Understanding the anatomy, embryology, and physiology associated with hydrocele formation is crucial to understand its onset and progression. Materials and Methods: A MEDLINE ${ }^{\oplus}$ search was conducted using keywords for the relevant classification of hydrocele and its etiology, complications, sexual barriers, evaluation, and management. Results: Appropriately classifying the hydrocele as primary, secondary communicating, secondary noncommunicating, microbe-induced, inflammatory, iatrogenic, trauma-induced, tumor-induced, canal of Nuck, congenital, and giant is important for identifying the underlying etiology. Often this process is overlooked when the classification or etiology is too rare. A focused evaluation is important for this, so that timely management can be provided. We comprehensively review the classifications, etiology, and secondary complications of hydrocele. Pitfalls of current diagnostic techniques
\end{abstract}

\section{KARGER}

두 2016 S. Karger AG, Basel

Fax +4161306 1234

E-Mail karger@karger.ch

www.karger.com
Accessible online at: www.karger.com/cur are explored along with recommended methods for accurate diagnosis and current treatment options. Conclusion: Due to the range of classifications and etiologies of hydrocele in the pelvis and groin, a deliberate differential diagnosis is essential to avoiding imminent life-threatening complications as well as providing the appropriate treatment.

Copyright $\odot 2016$ S. Karger AG, Basel

\section{Introduction}

A hydrocele is marked by a fluid-filled sac typically found in the scrotum, and less commonly in the external genitalia and pelvic regions. It may be a manifestation of certain severe underlying diseases. The fluid collection may result from patent processus vaginalis or an imbalance of secretion and absorption within the tunica vaginalis. A hydrocele can be organized into several classifications that can affect males and females of any ages. Hydrocele is characteristically painless, but can lead to physical and psychological complications. Further complications may be avoided if proper diagnostic and therapeutic techniques are employed. Upon discussing the anatomical, embryological, and physiological background of hydrocele, we comprehensively review its classifications, etiology, pathogenesis, secondary complications, evaluation, and management. Pitfalls of current diag- 


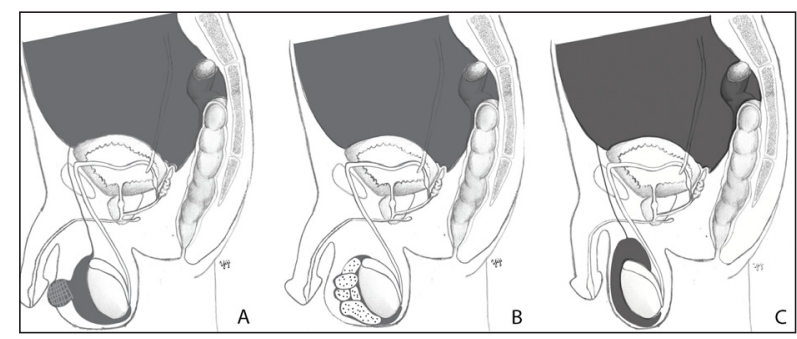

Fig. 1. Primary hydrocele. A Hernia of hydrocele, B multiloculated hydrocele, $\mathbf{C}$ vaginal hydrocele. Illustrated by Yiji Suh.

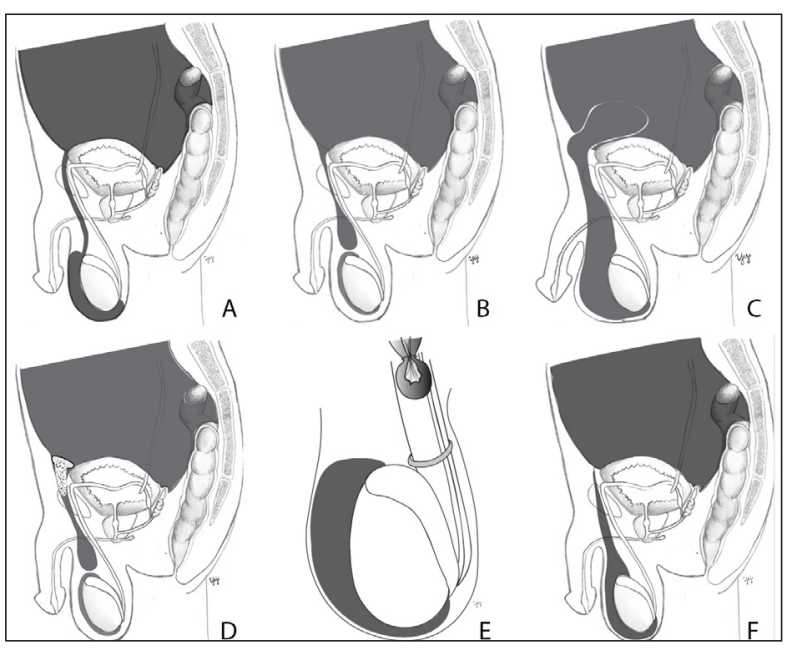

Fig. 2. Secondary communicating hydrocele. A Communicating hydrocele, B funicular hydrocele, $\mathbf{C}$ bilocular hydrocele (en-bisac), D hydrocele of the hernial sac, $\mathbf{E}$ hydrocele secondary to incarcerated hernia, $\mathbf{F}$ infantile hydrocele. Illustrated by Yiji Suh.

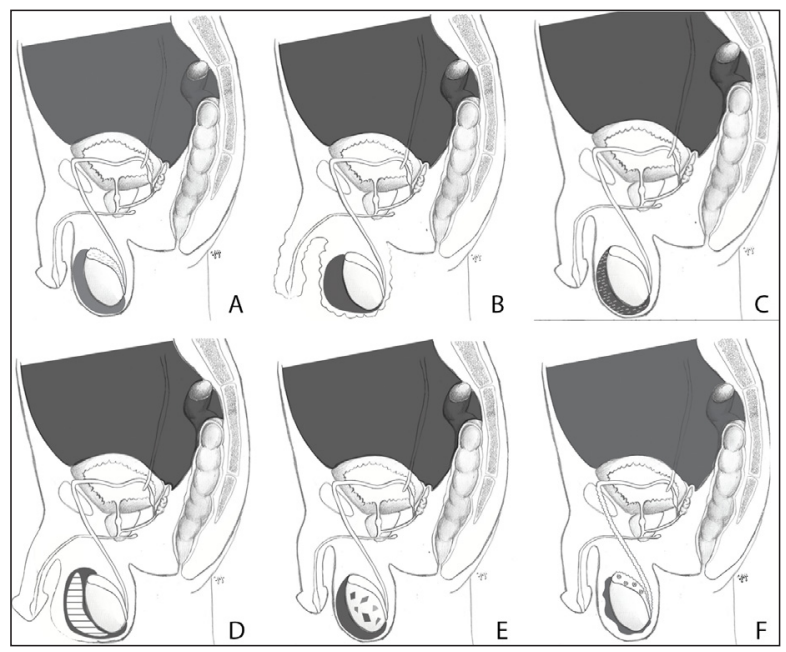

Fig. 4. Microbe-induced hydrocele. A) Parasitic hydrocele, B) elephantiasis hydrocele, C) filarial dance hydrocele, D) pyocele, E) syphilitic hydrocele, F) tuberculous hydrocele. Illustrated by Yiji Suh.

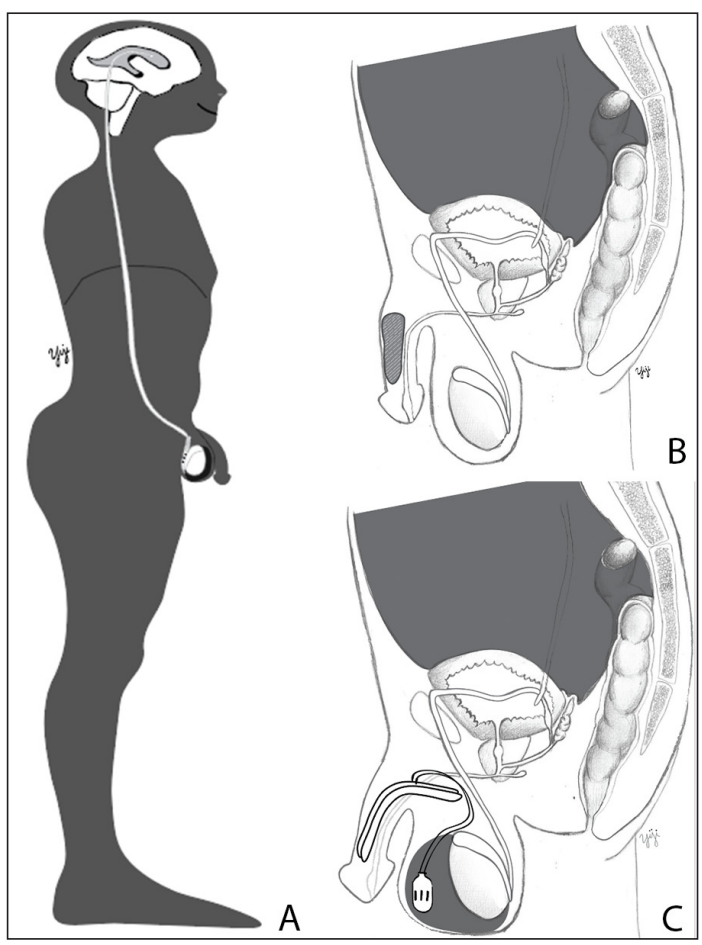

Fig. 5. Iatrogenic hydrocele. A Ventriculoperitoneal shunt resulting in hydrocele following migration of the peritoneal shunt, B penile hydrocele post-insertion of penile prosthesis, $\mathbf{C}$ reactive hydrocele following migration of penile prosthetic pump. Illustrated by Yiji Suh.

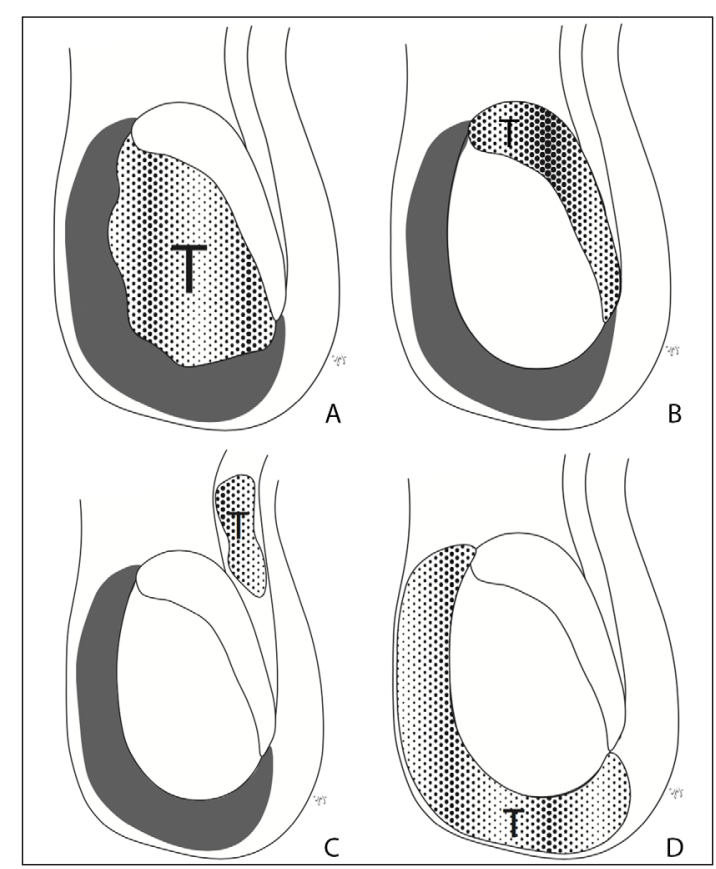

Fig. 6. Tumor-induced hydrocele; T: tumor. A Testicular tumor hydrocele, B epidydimal tumor hydrocele, $\mathbf{C}$ spermatic cord tumor hydrocele, D mesothelioma tumors of the tunica vaginalis. Illustrated by Yiji Suh. 


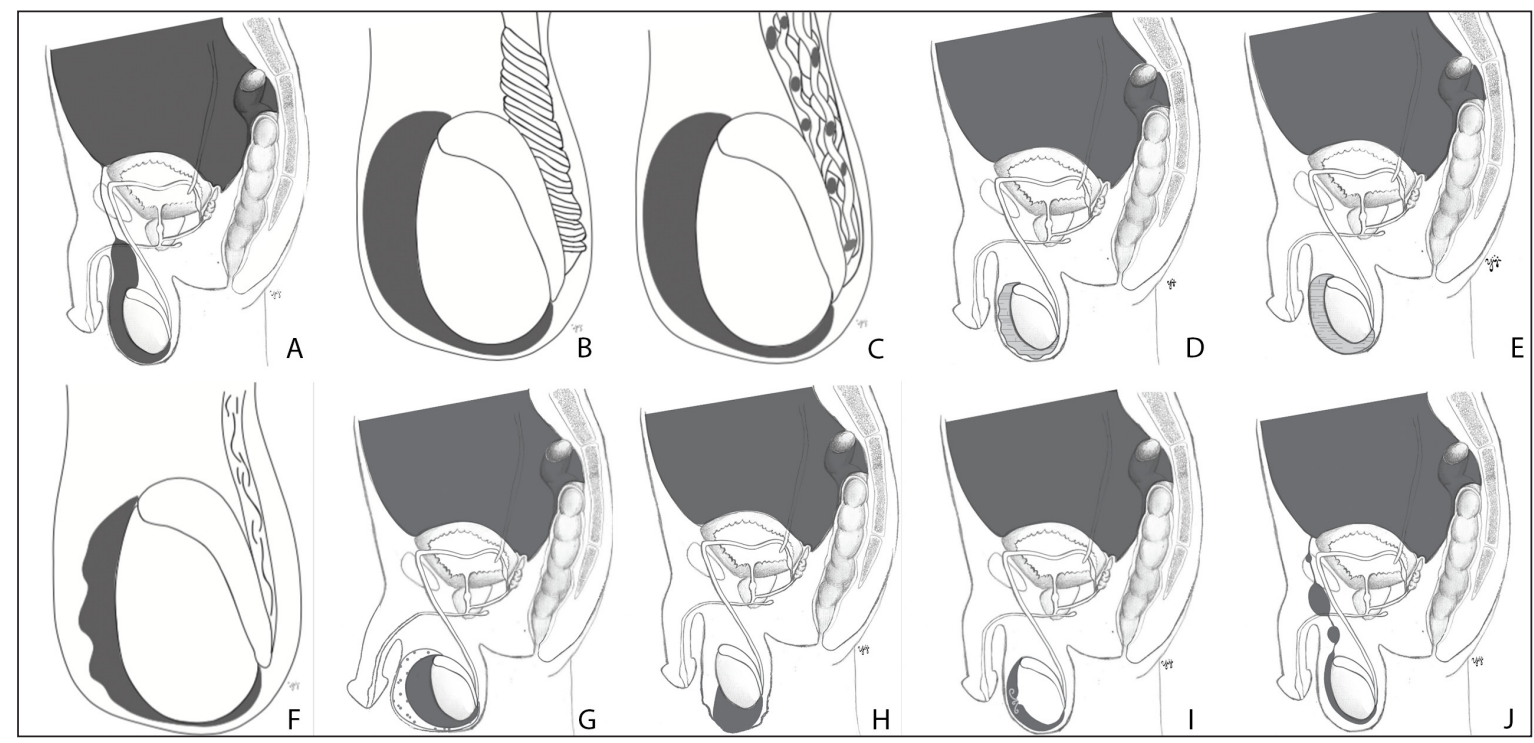

Fig. 3. Secondary noncommunicating hydrocele. A Noncommunicating hydrocele, B intermittent torsion, C thrombosed varicocele (venous-stasis), D lax hydrocele between the layers of tunica vaginalis, $\mathbf{E}$ tense hydrocele between the layers of tunica vaginalis, $\mathbf{F}$ hydrocele of lymph varix, $\mathbf{G}$ hydrocele of pneumoscrotum, $\mathbf{H}$ subtesticular hydrocele, I traumatic hydrocele/ hematocele, J encysted hydroceles of spermatic cord. Illustrated by Yiji Suh.

nostic techniques are explored along with recommended methods for accurate diagnosis and current treatment options.

\section{Anatomy, Embryology, and Physiology}

The inguinal region, or groin, is located at the bottom of the anterior abdominal wall. It embodies a tubular passage known as the inguinal canal, which spans from the pelvis to the groin. The inguinal canal has two openings: the deep inguinal ring and superficial inguinal ring. Though the structure of the canal is similar among males and females, its function varies with gender. For males, the canal allows the spermatic cord to pass between the testes and abdomen. In females, the canal provides a path for the round ligament of the uterus from the uterus to the labium majus.

During embryonic development, the inguinal canal also embodies the processus vaginalis, a structure that develops from the peritoneum during gestational week 12. In males, it extends through the inguinal canal into the scrotum, allowing the testes to descend into the scrotal sac. Following completion of testicular descent, the processus vaginalis undergoes programmed cell death to obliterate the path between the peritoneum and scrotum. After closure, the lower portion of the processus vaginalis becomes the tunica vaginalis testis. Failure to close results in a patent processus vaginalis, which leads to complications such as communicating hydrocele and inguinal hernia. Failure to close the processus vaginalis in females results in formation of a patent pouch of the peritoneum called the canal of Nuck. The canal of Nuck is also associated with complications of inguinal hernia and communicating hydrocele [1].

Hydrocele results from the collection of fluid in the bilayered tunica vaginalis. This fluid typically accumulates in infants due to the patent processus vaginalis, allowing peritoneal fluid to flow through the processus vaginalis into the scrotum and surround the testicle [2]. If the excess fluid cannot drain, accumulation results. The potential origins of fluid in the scrotum are outlined in table 1.

\section{Classification}

Hydroceles can be classified into primary (fig. 1), secondary communicating (fig. 2), secondary noncommunicating (fig. 3), microbe-induced (fig. 4), inflammatory, iatrogenic (fig. 5), trauma-induced, tumor-induced (fig. 6), canal of Nuck (fig. 7), congenital, and giant (fig. 8). A primary hydrocele is an idiopathic hydrocele with no known etiology. When diagnosed, a primary hydrocele is 

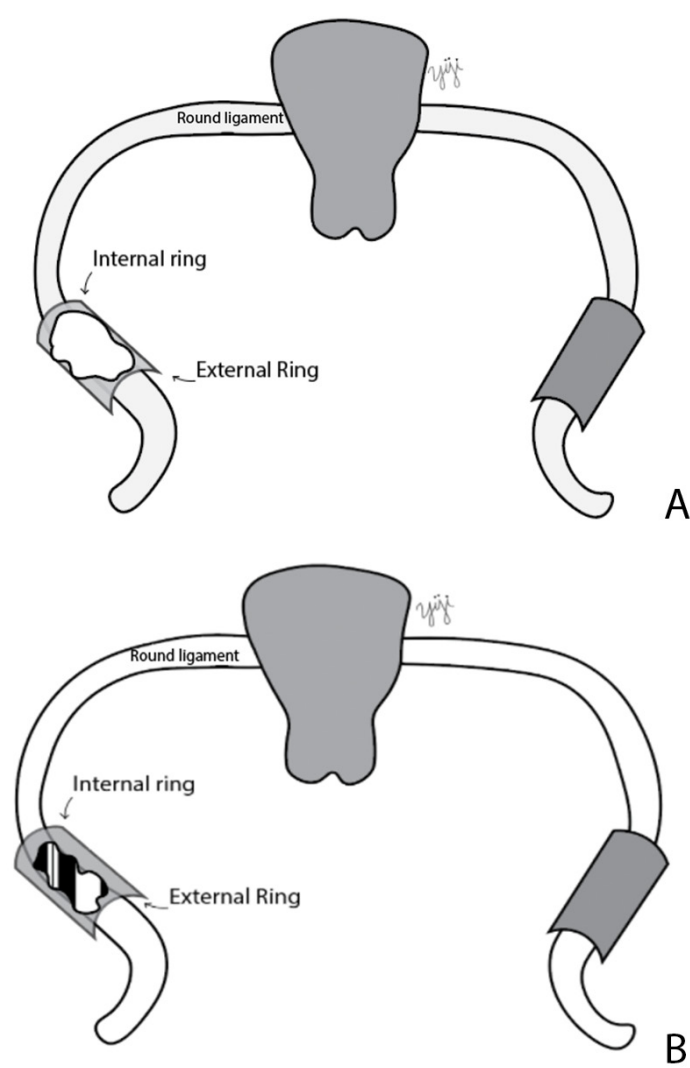

Fig. 7. Hydrocele of the canal of Nuck. Illustrated by Yiji Suh.

clinically tense and not palpable under physical examination. Secondary hydrocele includes communicating and noncommunicating hydrocele. These types of hydrocele underlying the testicle can be partially palpated under physical examination. Communicating hydrocele occurs when a path exists between the peritoneal cavity and scrotum or the peritoneal cavity and inguinolabial region. This path results from the patent processus vaginalis, which may be partial or completely open [3, 4], and not communicate with the abdomen while there is a small processus vaginalis or an entirely obliterated one. It is typically located in the tuinca vaginalis and does not change in size [5, 6]. Hydrocele may develop secondary to: dislocated testicle, testicular infarction, microlithiasis of testicle, lithiasis of tunica vaginalis, sarcoidosis of the testicle, retained foreign body (e.g. bullet or glass), as well as sharp object injury (e.g. icicle or toothpick).

Giant hydroceles are classified when the hydrocele is larger than the patient's head or larger than $1,000 \mathrm{ml}$ of content. The penis may become hidden. Although rare, there are few reported cases in the medical literature [7].

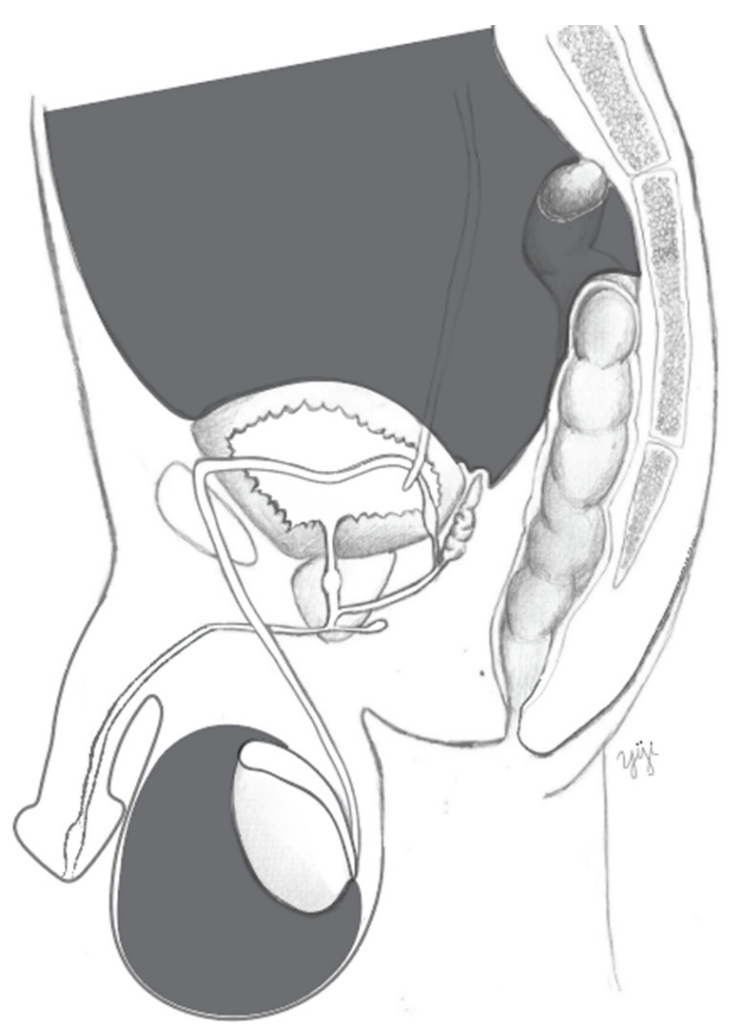

Fig. 8. Giant hydrocele. Illustrated by Yiji Suh.

Hydrocele of the canal of Nuck, also known as female hydrocele or cyst of the canal of nuck, affects infant females and results in painless or possibility painful inguinal swelling. It is an uncommon disease caused by the failure of the processus vaginalis to close during embryological development which can lead to inguinal hernia and hydrocele [8]. The enlargement of the cyst is likely due to an imbalance of secretion and absorption of fluid of the secretory membranes that envelope the processus vaginalis. Possible causes of the imbalance in lymphatic drainage are trauma and infection; it is most frequently idiopathic [9]. Hydrocele of the undescended testicle is a congenital cause in males.

Parasitic hydrocele is associated with hydatid cysts and filariasis. Hydatid disease, also referred to as echinococcosis, is a major problem in Mediterranean countries [10] and can sometimes present as hydrocele [11, 12]. Filarial hydrocele is a type of lymphatic filariasis prevalent in patients of developing countries [13]. It is caused by a mosquito-born parasite called Wuchereria bancrofti and affects 100 million people worldwide. Fi- 
Table 1. Collection of biological fluids within the scrotum presenting as hydrocele

\begin{tabular}{ll}
\hline Fluid or condition & Causes \\
\hline Subcutaneous emphysema & $\begin{array}{l}\text { iatrogenic, gas-producing infection, scrotal } \\
\text { trauma, pneumothorax [34] } \\
\text { angiokeratoma of the scrotum, urinary } \\
\text { tract tumors, varicoceles, hernias, intra-ab- } \\
\text { dominal mass [35], hemoperitoneum from } \\
\text { splanchnic hematoma [36], patent proces- } \\
\text { sus vaginalis [37] }\end{array}$ \\
laparoscopic cholecystectomy [38] \\
Bile & $\begin{array}{l}\text { ventriculoperitoneal shunt [31] } \\
\text { abdominoscrotal hydrocele [39] }\end{array}$ \\
Peritoneal fluid & $\begin{array}{l}\text { Fournier's gangrene secondary to hydro- } \\
\text { cele [40, 41] }\end{array}$ \\
filariasis [42], laparoscopic treatment [43] & $\begin{array}{l}\text { renal transplant [44], ureteral calculus } \\
\text { drainage from a scrotal incision [45] }\end{array}$ \\
Lymphocele & $\begin{array}{l}\text { air accumulation from the lung, retroperito- } \\
\text { neal sources, infection with gas producing } \\
\text { bacteria, surgical manipulations [46] }\end{array}$ \\
Pneumoscrotum & $\begin{array}{l}\text { utero perforation of the bowel, spillage into } \\
\text { peritoneal cavity [47] } \\
\text { Wilms tumor, tumor invading tunica albug- } \\
\text { inea and vaginalis testis [48, 49] } \\
\text { hematocele, calculus formation [7] }\end{array}$ \\
Meconium & \\
Tumor-induced & \\
Giant hydrocele & \\
\hline
\end{tabular}

larial hydrocele is one of the most common complications of lymphatic filariasis [14] and can be extremely dangerous due to potential rupture of lymph fluid from dilated lymphatic vessels, which may complicate testicular function [15]. The fluid of hydrocele is prone to infection. In endemic parts of India, West and East Africa, and Saudi Arabia, microfilaria can infect hydrocele fluid leading to further complications [16]. Studies conducted Nigeria and Nepal $[13,14]$ report the need for elimination of lymphatic filariasis. Advances in treatment options, control, diagnosis, and clinical understanding have led to anti-filariasis campaigns [17, 18].

Both hydrocele and hernias are common throughout infancy and childhood; inguinal hernia repair is one of the most common surgeries performed during these times [19]. Hernias and hydroceles typically occur together due to similar pathology. They both result from an abnormality with the processus vaginalis [20]. Hydrocele of the femoral hernial sac is a rare class of hydrocele, which generally alludes to presence of an actual femoral hernia [21]. Hydrocele of the femoral hernia can be classified as communicating or noncommunicating [22]. It may be difficult to prediagnose hydrocele of the femoral hernia without exploration due to an irreducible or incarcerated femoral hernia obstructing the hydrocele [23].
Table 2. Etiology of painful hydrocele

\begin{tabular}{ll}
\hline Etiology & Reference \\
\hline Infected hydrocele & {$[55]$} \\
Encysted hydrocele of the spermatic cord & {$[56]$} \\
Torsion of hernial sac & {$[57]$} \\
Testicular torsion & {$[58]$} \\
Epididymitis & {$[3]$} \\
Torsion of testis and appendages & {$[59,60]$} \\
Thrombosis of dorsal vein of the penis & {$[61]$} \\
Priapism & {$[61]$} \\
Peyronie's disease & {$[61]$} \\
Urethritis & {$[61]$} \\
Impacted stone in the urethra & {$[61]$} \\
Urethral stricture & {$[61]$} \\
Eversion of prepuce & {$[61]$} \\
Frenular tear & {$[61]$} \\
Balanitis and balano-opisthitis & {$[61]$} \\
Hernia of hydrocele & {$[61]$} \\
Hydrocele of hernia & {$[61]$} \\
Strangulated groin or femoral hernia & {$[61]$} \\
\hline
\end{tabular}

Iatrogenic disruption of the lymphatic system can cause hydrocele. Post-varicocelectomy hydrocele occurs through disruption of lymphatics around the spermatic cord. This postoperative complication has an occurrence rate of 3-33\% [24]. Hydroceles have been reported as postoperative complications for inguinal herniotomies (IH), ventriculoperitoneal shunts, and renal transplants $[25,26]$. The hydrocele resulting from an IH typically resolves without further treatment [27] Prevention of a postoperative hydrocele from IH is carried out by careful incisions during surgery. For example, overzealous excisions of fat along the spermatic cord and careful ligatures of lymphatics are some methods for prevention [28]. Ventricoperitoneal shunts for treatment of hydrocephalus may migrate into the right hemiscrotum through the processus vaginalis, leaking cerebrospinal fluid [29-31]. Hydrocele following renal transplant presents dangerous complications. The hydrocele may become infected with bacteria post-transplantation. For example, a renal transplant patient experienced hydrocele with cutaneous group A $\beta$-hemolytic streptococcal infection [32]. Another renal transplant patient presented with seminoma and hydrocele [33]. Other iatrogenic etiologies include: hydrocele post-radiotherapy of spermatic cord or groin, hydrocele post-varicocelectomy or herniorraphy, hydrocele of ectopic testicle post-transposition, hydrocele post-testicular biopsy, as well as hydrocele of testicular prosthesis. 


\section{Etiology}

Among the many causes of hydrocele, the most common tends to be the disruption of the lymphatic system. Surgeries, such as laparoscopic varicocelectomy, can either partially or completely disrupt testicular lymphatic drainage, which leads to the postoperative complication of hydrocele [50]. The imbalance of drainage and input into the lymphatic tissue surrounding the scrotum is another cause of hydrocele $[9,51]$. The potential causes of painful hydrocele are listed in table 2 .

When hydrocele is the noncommunicating type, aquaporin channels may be responsible. Hattori et al. [52] investigated the expression of aquaporin channels in relation to noncommunicating hydrocele. Tunica vaginalis of patients with hydrocele were studied and then compared to a non-hydrocele infected male control. Western blot analysis was used to find aquaporin channels 1 and 3. Aquaporin channels function to regulate water flow across the plasma membrane, and an abnormality with these channels could be linked to hydrocele formation. The study concluded by noting an overexpression of aquaporin channel one within the tunica vaginalis in patients with a hydrocele. The hydrocele fluid may manifest from increased fluid output from capillaries that contain the overexpressing aquaporin channel 1, leading to lymphatic drainage that is less than the output. This pioneering study leads to speculation and should encourage further exploration as to the role of aquaporin channels and their connection to hydrocele.

Giant hydroceles are caused mostly due to phobia and neglect from the patient. They are most likely to be encountered in poor third world countries where the patient does not have the means or resources to treat the hydrocele. When a giant hydrocele is not treated, it has serious implications on the patient's quality of life [7].

A hydrocele can also occur after renal transplantation. This arises most probable because of lymphatics that have been disturbed. Penn et al. [53] discusses a study consisting of a series of renal transplantations and testicular complications. Hydrocele was the most common complication due to a disruption of lymphatic channels along the iliac vessel. The lymphatic disruption caused the hydrocele because it negatively affected the absorption of the lymphatics despite regular secretion of the fluid.

A rheumatoid hydrocele is a rare manifestation of hydrocele. Ijaz [54] reports a 53-year-old male who underwent hydrocele repair surgery with brown deposits on the inside of the tunica vaginalis. The deposits were biopsied and identified as vascular fibrous tissue with foci of necrobiosis, surrounded by palisaded macrophages. This is a characteristic of a rheumatoid-like tissue response. This immune response towards the tunica vaginalis could be the explanation as to why this patient developed hydrocele.

\section{Secondary Complications}

Masses that abnormally present within the scrotum have the potential to affect negatively the surroundings. The pressure within the testis can decrease the efficiency of spermatogenesis. According to 120 biopsies conducted by Dandapat et al. [62], patients with and without hydrocele, those with hydrocele exhibited atrophy in $8 \%$ and flattening of the testis in $22 \%$ of cases studied. Ten percent of affected patients had a partial arrest of spermatogenesis while $8 \%$ had a total arrest. Other histological findings include thickening of the basement membrane, tunica albuginea, and tunica vaginalis. The arrests of spermatogenesis likely due to increased pressure on the blood supply on the testis from edema [62, 63].

Failure to perform spermatogenesis may also result from a rise in intrascrotal temperature [62]. Water, which has a very high specific heat compared to other liquids, is the major component of hydrocele. Due to resistance to the thermoregulatory mechanism, water can hold onto heat very well, leaving the area incapable of heat dissipation. High heat from water being trapped within the scrotum leaves the scrotum at a temperature too high for optimum spermatogenesis $[64,65]$. Semen quality has been shown to decrease by $40 \%$ for every $1{ }^{\circ} \mathrm{C}$ the scrotum increases [66]. Hydrocele has a direct link to male infertility.

Benign and malignant tumors of the tunica vaginalis may be overshadowed by hydrocele. Zaslau et al. [67] discuss a case of a malignant tumor of the tunica vaginalis that was disguised as a hydrocele. The patient initially presented with a large scrotal mass that was not tender and transilluminated. He complained of discomfort and a heavy feeling. The patient underwent a hydrocelectomy due to an initial diagnosis of noncommunicating hydrocele. With examination of the hydrocele sac, carcinoma was found arising from the tunica vaginalis. This case presents the possibility for hydrocele to mask underlying problems and underlying problems, including tumors of tunica vaginalis [68]. 
Though hydrocele typically presents as a painless mass, it can lead to psychological complications responsible for sexual dysfunction and infertility. Gyapong et al. [69] examined the burden of hydrocele within a community in Ghana. The authors found that unmarried men with hydrocele could not find a spouse due to negative associations of hydrocele. Sexual dysfunction was prevalent among married men with hydrocele, exhibiting a decrease in sexual desire and difficulty to have to become tumescent. Infertility is another factor contributing to the psychological burden of hydrocele patients [7]. Men fear hydrocele formation due to sexual and social disadvantages that can arise from a hydrocele present $[69,70]$. The sexual barriers of hydrocele include pain and dyspareunia, infertility, ejaculatory disorder, pseudo shortening of penis, erectile dysfunction, buried penis, social stigma, embarrassment and body dysmorphic disorder [72]. Hydrocele may produce infertility due to compartment syndrome, compression, and increased temperature of hydrocele, as water is resistant to transmission of heat [71].

Traumatic, inflammatory and painful complications of hydrocele include rupture, pain, pyocele, infection, hematocele, and intertrigo of the scrotal wall, and sexual dysfunction secondary to buried penis. Hydrocele rupture can occur spontaneously or due to trauma or pressure directed on the hydrocele sac [73, 74]. Pain associated with hydrocele may result from acute attacks of scrotum, penis, or urethra and may present as tenderness, dull aches, and pulling sensations $[69,75]$. Infections of hydrocele can be morbid if not treated immediately. Sarwar et al. [40] reported a case of an infected hydrocele leading to Fournier's gangrene, a type of necrotizing fasciitis. Days after treatment of this painless hydrocele, spreading cellulitis and necrosis were observed. Hydrocele aspiration leaves patients with a predisposition towards Fournier's gangrene. Bacteria exposure, such as that resulting from a ruptured appendix, may lead to infection of an already present hydrocele [76, 77]. Hematocele may be caused by aspiration, trauma, or rupture. A rupture of an abdominoscrotal hydrocele causing hematocele requires immediate surgical treatment [78].

Deposition of organic matter within the bilayered tunica vaginalis can result from hydrocele. Scrotal calculi and hydrocele stones can be found during hydrocele repair surgery. Infrared spectroscopy is helpful in determining the composition of organic masses. Stones can form regardless of hydrocele size and originate from fibrous deposits in the tunica vaginalis after trauma or inflammation. These masses are rarely reported but re-

Hydroceles of the Pelvis and Groin main common in clinical practice [79]. Long-term hydrocele may be a predisposing factor for complications such as focal thickening of tunica vaginalis and lobulated masses mimicking epididymal tumors [80]. Infection of hydrocele fluid may lead to a multiloculated hydrocele, secondary to epididymi-orchitis.

Appendicitis can cause an infected hydrocele if the hydrocele can communicate with the abdomen cavity and the hydrocele sac. In a case report by Lantsberg et al. [81], a 20-year-old patient had a laparoscopic appendectomy and then acquired an infected hydrocele as a result. The authors recommended avoiding laparoscopic surgery in patients with a hydrocele. Hydrocele can also be the cause of appendicitis. An abdominoscrotal hydrocele compressed on the appendix, causing compression and subsequently, appendicitis. Appendicitis can be caused and complicated by variations of hydrocele [82].

Hydrocele can cause stress to other tissues around the body, especially sensitive ones like the testis. The pressure in a hydrocele can become so great that it surpasses the blood pressure of the blood vessels within the scrotum and results in ischemia. From this, a study by Wright et al. [83] found that tension from a hydrocele caused testicular ischemia. This situation is comparable to testicular compartment syndrome and upon diagnosis, any pain accompanied with hydrocele should be ruled out when coming to a diagnosis. Other types of stress a hydrocele can cause include a social perspective. A giant hydrocele may completely change how the individual lives their life. Giant hydroceles affect the patient's work capacity, sexual function, and overall quality of life. The weight alone is discomforting and pulls at the skin and impairs the patient's mobility. Giant hydrocele has also created hardships such as teasing, sexual dysfunction, divorce due to unsuitability for marriage, as well as difficulty in wearing proper attire. Foul odor from intertrigo may cause embarrassment. Physical complications include pressure necrosis along with wound infection, hematocele, calcification of the sac, infertility, and calculus formation [7].

Insertion of the Three-Piece Penile Prosthesis may pose a significant problem in patients with hydrocele. The pump in the scrotum would become difficult to activate and deactivate. This is a preoperative problem in patients with hydrocele.

As mentioned above, the complications include sexual dysfunction, infertility, rupture, pain, pyocele, infection, Fournier's gangrene, hematocele, intertrigo, scrotal calculi, hydrocele stones, appendicitis, and testicular ischemia. 
Table 3. Differential diagnosis of hydrocele and scrotal wall swelling

\begin{tabular}{ll}
\hline Scrotum disorder & Cause \\
\hline Testicular torsion & $\begin{array}{l}\text { Henoch-Schönlein purpura [101], bell clap- } \\
\text { per deformity [102] }\end{array}$ \\
$\begin{array}{l}\text { Henoch-Schönlein purpura } \\
\text { vesticular appendage }\end{array}$ & vasculitis [101] [103] \\
Varicocele & $\begin{array}{l}\text { patent internal spermatic veins, Increased } \\
\text { venous pressing in renal vein, collateral ve- } \\
\text { nous anastomoses [103] }\end{array}$ \\
penetration of body \\
Tumor & $\begin{array}{l}\text { carcinoma of sigmoid colon [104], testicular } \\
\text { masses [105] }\end{array}$ \\
idiopathic, mosquito bite, allergies, anaph- \\
ylaxis, ascites, anasarca, cirrhosis of liver, \\
idiopathic edema of scrotum, hypoproteine- \\
mia, nephrotic syndrome, bites, fat necrosis \\
of scrotum, filariasis, allergies, cellulitis, \\
elephantiasis, congested heart failure \\
systemic infection, noninfectious etiologi- \\
cal factors [106] \\
leak of dialysate into an inguinal hernia or \\
anterior abdominal wall [107] \\
effusion of fluid into extracellular space \\
[108]
\end{tabular}

Table 4. Cystic inguinal and scrotal masses

\begin{tabular}{|c|c|}
\hline Testicular masses & Non-Testicular masses \\
\hline Torsion of the testicular appendage & epididymitis \\
\hline Testicular torsion & bladder Hernia \\
\hline Spermatocele & bladder diverticulum \\
\hline Hydrocele & urethral diverticulum \\
\hline Varicocele & syringocele \\
\hline Testicular cancer & testicular cysts \\
\hline Epidermoid cyst [109] & epididymal cysts \\
\hline Simple cyst [109] & cystic tumors of testicle \\
\hline Granulosa cell tumor [109] & lymphangioma \\
\hline Dermoid cyst [109] & massive inguinal hernia \\
\hline Prepubertal teratoma [109] & $\begin{array}{l}\text { congenital diaphanous distended } \\
\text { loop of bowel (mistaken on tran- } \\
\text { sillumination) }\end{array}$ \\
\hline Massive lipoma of the testicle & fat necrosis of the scrotal wall \\
\hline
\end{tabular}

\section{Evaluation}

\section{Clinical Evaluation}

Transillumination is one of the most common techniques used to diagnose hydrocele. It is widely believed that if light shines through the scrotum during transillumination, the mass is cystic, and if the light is blocked, the mass is solid [84]. The ability of light to pass through
Table 5. Cystic masses of the round ligament in females

\section{Mass}

\section{Endometriosis}

Inguinal endometriosis

Carcinoma

Dermoid cysts

Inguinal hernia cysts

Cystic adenomyosis

Cystocele

Varicosities

Varicocele

Mesothelial cysts

Hydatid cysts

an object depends on the object through which the light passes. If an object is less permeable, then less light will shine through it. Factors that play a role in light permeability include density, thickness, and size. Thickening of the tunica vaginalis prevents accurate hydrocele identification via transillumination. Thick-walled tissue creates a situation where light cannot pass through and leaves transillumination ineffective [80]. Other barriers to transillumination that prevent light from passing through the scrotum include hydrocele calculi, hydroceles stones, testicular calcifications, bowel obstruction, and hernia $[79,85]$. Tumors accompanied with hydrocele can obstruct the transillumination [86]. Other options should be considered when diagnosing hydrocele; scrotal ultrasonography with duplex Doppler is an appropriate test for hydroceles.

\section{Imaging Studies}

Duplex Doppler sonographic assessment is the recommended diagnostic tool for identifying hydrocele. This method identifies hydrocele in patients that may have intrascrotal calcifications or non-palpable hydrocele [87]. Ultrasonography helps eliminate misdiagnosis, especially when hydrocele is accompanied with tumors [88]. Ultrasound may be used to prenatally diagnose infants for inguinal or scrotal hernia as well as contralateral hydrocele. Using a multifrequency $3 \mathrm{D}$ transducer, a sonographic hydrocele is presented as a crescent shape. Finding and identifying scrotal masses in neonatal patients is important as they can be treated more readily [89]. Patients should be placed in both supine and upright positions during examination as the hydrocele may reduce into the abdomen depending on the position of the patient [90]. 


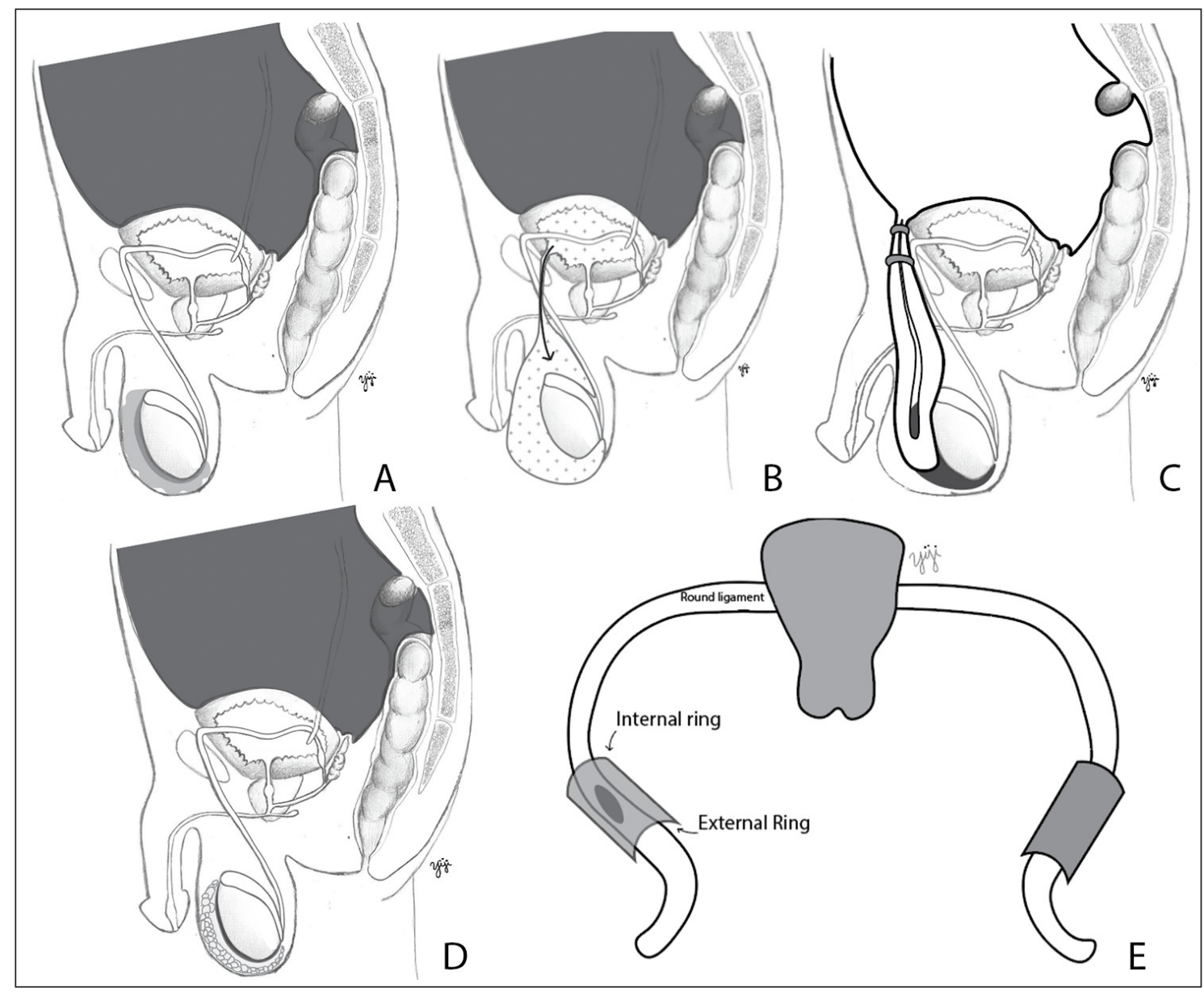

Fig. 9. Hydrocele imitations. A Scrotal edema, B bladder diverticulum, C congenital diaphanous distended loop of bowel (mistaken on transillumination), D fat necrosis of the scrotall wall, E mesothelial cysts. Illustrated by Yiji Suh.

Color Doppler ultrasonography is a great variation of duplex Doppler diagnosis. Color Doppler ultrasonography can help differentiate scrotal masses and diseases. Color Doppler ultrasonography can also help identify anatomy and perfusion in real time for the scrotal area. This method can identify intratesticular versus extratesticular abnormalities. Sensitivity to scrotal disease is reported to be $98 \%$ with $68 \%$ specificity. The main advantage of color Doppler ultrasonography over grey scale is that grey scale lacks specificity for parenchymal changes, and benign and malignant lesions cannot be distinguished from one another. Ultrasonography is the first and most often the only option needed to make a diagnosis. The resistive index is another aspect that is important to consider when undergoing diagnostic testing. The resistive index for a normal testicle is low, while hydrocele presents with a high resistive index spectral flow pattern
[91]. When color Doppler ultrasonography presents with inconclusive data, magnetic resonance imaging (MRI) should be the next viable diagnostic measure [92]. Imaging should be performed with upright and supine position from internal ring to the bottom of the scrotum to determine the pathophysiology.

Computed tomography (CT) scan with and without contrast is an appropriate imaging study in patients with complex undiagnosed or difficult to diagnose hydrocele on ultrasound. Hydrocele or hydrocele associated with inguinal, femoral hernias, appendicitis, sudden-onset, painful, febrile or other iatrogenic hydrocele, or other etiology should utilize scrotal ultrasound and duplex Doppler, followed by CT scan [93].

MRI of the scrotum or inguinal canal region provides additional information and increases diagnostic accuracy. Examples of additional information that has been 
Table 6. Sclerosing agents and their complications or cure rate

\begin{tabular}{ll}
\hline Sclerotherapy & Complications or cure rate \\
\hline Polidocanol & pain, scrotal edema, swollen epididymis [113] \\
Doxycycline & {$[111]$} \\
Tetracycline & $\mathrm{n}=15,33.3 \%[114], \mathrm{n}=27,85 \%[115]$ \\
OK-432 & mild fever, inflammatory reaction [116] \\
Ethanolamine oleate & $\mathrm{n}=100,98 \%$ \\
Phenol & $\mathrm{n}=40,95 \%[117]$ \\
Antazoline & $14 \%[118]$ \\
\hline
\end{tabular}

brought up through MRI include intratesticular hematoma, hematoceles, and extension of the inguinal canal. An MRI can check for possible misdiagnosis made through ultrasonography. In one case, an albuginea of an intact testis was misdiagnosed as a line of fracture [94]. It is also useful to have an MRI done when the case at hand presents with difficulty. Such difficulties include scrotal wall thickening, calcinosis, hydrocele stones or tumors [95-98]. These occurrences can provide difficulty in the visualization of the scrotum and its contents so therefore an MRI is essential. An MRI examination prevents unnecessary surgical exploration, which will ultimately reduce overall costs and length of hospitalization for the patient [94].

\section{Differential Diagnosis}

Different pathologies can exhibit symptoms mimicking those of hydrocele (tables 3-5). The differential diagnosis also includes: lipomatosis of the lower anterior abdominal wall causing hidden penis, saxophone penis [99], and webbed penis [100]. Examples of conditions imitating hydrocele are depicted in figure 9.

\section{Management}

There are two categories of surgical treatment, invasive and noninvasive. Each offers advantages over the other, but whether or not a single method is preferred is yet to be established [110].

\section{Noninvasive Options}

Detailed examination and ultrasound with duplex Doppler in upright and supine position must be performed before aspiration and sclerosing agents are used to treat hydrocele. Two of the more frequently used noninvasive treatment options are aspiration and sclerotherapy. These methods are best used in conjugation with each
Table 7. Contraindication for Hydrocele Sclerotherapy

\begin{tabular}{ll}
\hline Contraindication for ydrocele sclerotherapy & Reference \\
\hline Congenital hydrocele & {$[119]$} \\
Communicating hydrocele & {$[119]$} \\
Hydrocele in children & {$[119]$} \\
Hydrocele with hernia & {$[119]$} \\
Hernia of a hydrocele & {$[119]$} \\
Hydrocele with varicocele & {$[119]$} \\
Painful hydrocele & {$[119]$} \\
Funicular hydrocele & {$[119]$} \\
Hydrocele-enbissac & {$[119]$} \\
Multiocular hydrocele & {$[119]$} \\
Encysted hydrocele of cord & {$[119]$} \\
Subtesticular hydrocele & {$[119]$} \\
Secondary hydrocele with suspected tumors of & {$[119]$} \\
tunica vaginalis & \\
Traumatic hydrocele & {$[120,121]$} \\
Calcification of tunica vaginalis & {$[120,121]$} \\
Allergic sensitivity to scerosant & {$[122]$} \\
Pregnancy - hydrocele of canal of Nuck & {$[122]$} \\
Infections hydrocele with concealed/hidden penis & {$[122]$} \\
Deep venous thrombosis & {$[122]$} \\
Severe arterial disease & {$[122]$} \\
\hline
\end{tabular}

Table 8. Surgical options for the treatment of hydrocele

\begin{tabular}{ll} 
Treatment & Effective \\
\hline Quinine urethane & Yes [128] \\
Fibrin glue applications therapy & No [129] \\
Hydrocelectomy & Yes [124] \\
Minimal access hydrocelectomy & Yes [126]
\end{tabular}

other. When hydrocele is treated with aspiration alone, it typically reappears [110]. According to one study, aspiration and sclerotherapy with doxycycline has an $84 \%$ success rate. There are other types of sclerosing agents besides doxycycline that may be used with sclerotherapy; they are presented in table 6. Such agents may be considered just as successful as hydrocelectomy. Size of the hydrocele can be a useful measurement for predicting whether treatment will benefit a patient. A hydrocele size of more than $750 \mathrm{ml}$ is a cutoff point for some treatments. Aspiration and sclerotherapy are less expensive than hydrocelectomy. One estimate by Rush University Medical Center puts the cost for aspiration and sclerotherapy at $\$ 459.13$ and hydrocelectomy at $\$ 12,322.34$ [111]. Complications that may arise from aspiration and sclerotherapy treatment include recurrence of the hydrocele and partial gangrene [112]. Some predispositions that are considered contraindications for sclerotherapy are discussed in table 7. 
In a rare situation, a diver suffered from decompression illness and manifested hydrocele. Bubbles in body fluid, coming from dissolved inert gas were present, which resulted in tissue swelling. An obstruction of lymphatic drainage from nitrogen bubbles was the speculated cause of hydrocele formation. The patient was treated with a hyperbaric oxygen chamber and the hydrocele resolved itself spontaneously, prompting this method of treatment for hydrocele patients with a history of recent diving [123].

\section{Surgical Procedures}

Hydrocelectomy is one of the main surgical treatments for hydrocele. This procedure is highly recommended when the hydrocele is large and persistent [124]. Hydroceletomy is more invasive compared to its nonsurgical counterpart, but in some cases has a higher success rate. The main drawback of hydrocelectomy is its postoperative complications. Postoperative complications include scrotal edema, hematoma, chronic pain, decreased fertility, persistent swelling, Fournier's gangrene, and infection [125-127]. Minimal access hydrolecetomy is a suggested alternative because it is less invasive and involves a smaller incision. A new minimal access hydrocelectomy is described by Saber that minimizes traumatic insult to the patient without sacrificing safety and efficacy. The operative time is quick (12-18 minutes) and recovery time is shortened in comparison with a traditional hydrocelectomy [126]. The available surgical options are listed with their effectiveness in table 8.

\section{Alternative Treatment}

Infants who present with a hydrocele should undergo a more conservative approach to their hydrocele repair if little or no complications are present. Koski et al. conducted a study with infants being treated for communicating hydroceles. The authors proposed taking a more conservative approach for treating these infants. In the study, by simply avoiding surgery in half of the patients below the age of 18 months, the authors concluded it was the safest and most effective method for treating hydroceles in that age range [130].

\section{Conclusion}

Numerous etiologies are responsible for hydroceles that can be classified as primary, secondary communicating, secondary noncommunicating, microbe-induced, inflammatory, iatrogenic, trauma-induced, tumor-induced, canal of Nuck, congenital, and giant. Hydrocele should be taken seriously and monitored closely whether it is present in infants or older patients, especially when rare secondary complications are a threat to the patient's life or quality of life. Diagnosis of hydrocele should shift away from transillumination and more towards radiologic imaging in both supine and upright positions. All treatment options should be considered before eliminating methods on a case-by-case basis.

\section{Acknowledgements}

The authors are thankful to Drs. Kelly Warren, Todd Miller, and Peter Brink for departmental support, as well as Mrs. Wendy Isser and Ms. Grace Garey for literature retrieval. 


\section{References}

1 Yen CF, Wang CJ, Lin SL, Chang PC, Lee CL, Soong YK: Laparoscopic closure of patent canal of Nuck for female indirect inguinal hernia. J Am Assoc Gynecol Laparosc 2001; 8:143-146.

2 Valentino M, Bertolotto M, Ruggirello M, Pavlica P, Barozzi L, Rossi C: Cystic lesions and scrotal fluid collections in adults: Ultrasound findings. J Ultrasound 2011;14:208215.

3 Barthold JS, Redman JF: Association of epididymal anomalies with patent processus vaginalis in hernia, hydrocele and cryptorchidism. J Urol 1996;156:2054-2056.

4 Rahman N, Lakhoo K: Patent processus vaginalis: a window to the abdomen. Afr J Paediatr Surg 2009;6:116-117.

5 Christensen T, Cartwright PC, Devries C, Snow BW: New onset of hydroceles in boys over 1 year of age. Int J Urol 2006;13:14251427.

6 Wilson JM, Aaronson DS, Schrader R, Baskin LS: Hydrocele in the pediatric patient: inguinal or scrotal approach? J Urol 2008;180(4 suppl):1724-1727.

7 Akpo EE: Giant hydrocele--an epitome of neglect. Afr Health Sci 2005;5:343-344.

8 Akkoyun I, Kucukosmanoglu I, Yalinkilinc E: Cyst of the canal of nuck in pediatric patients. N Am J Med Sci 2013;5:353-356.

9 Ozel A, Kirdar O, Halefoglu AM, Erturk SM, Karpat Z, Lo Russo G, Maldur V, Cantisani V: Cysts of the canal of Nuck: ultrasound and magnetic resonance imaging findings. J Ultrasound 2009:12:125-127.

10 Bouchikhi AA, Lamrani YA, Tazi MF, Mellas S, Elammmari J, Khallouk A, Elfassi MJ, Farih MH: Unilateral primitive hydatid cyst with surgical resection of the scrotum: a case report. J Med Case Rep 2013;7:109.

11 Haouas N, Sahraoui W, Youssef A, Thabet I, Ben Sorba N, Jaidane M, Mosbah AT: Hydatid cyst of the spermatic cord. Prog Urol 2006;16:499-501.

12 Zikrillaev A: Hydatid echinococcosis of paravesicular cellular tissue, simulating hydrocele. Urologiia 2002;3:55.

13 Sherchand JB, Obsomer V, Thakur GD, Hommel M: Mapping of lymphatic filariasis in Nepal. Filaria J 2003;2:7.

14 Christiana O, Olajumoke M, Oyetunde S: Lymphatic filariasis and associated morbidities in rural communities of Ogun State, Southwestern Nigeria. Travel Med Infect Dis 2014;12:95-101.

15 Noroes J, Dreyer G: A mechanism for chronic filarial hydrocele with implications for its surgical repair. PLoS Negl Trop Dis 2010;4:e695.

16 Chandran PA, Jayaram G, Mahmud R, Anuar AK: Microfilaria in hydrocele fluid cytology. Malays J Pathol 2004;26:119-123.

17 Ottesen EA: Lymphatic filariasis: Treatment, control and elimination. Adv Parasitol 2006; 61:395-441.
18 Ottesen EA, Duke BO, Karam M, Behbehani $\mathrm{K}$ : Strategies and tools for the control/elimination of lymphatic filariasis. Bull World Health Organ 1997;75:491-503.

19 Kapur P, Caty MG, Glick PL: Pediatric hernias and hydroceles. Pediatr Clin North Am 1998;45:773-789.

20 Irabor DO, Ogundoyin O O, Ogunlana DI: Pregnancy, parturition, parity and position in the family. Any influence on the development of paediatric inguinal hernia/hydrocele? Niger J Med 2014;23:311-314.

21 McCorkle HJ, Bell HG: Hydrocele of the femoral hernial sac. Ann Surg 1941;113:264267.

22 Abdellah AA, Musa AM, Bashier $\mathrm{OH}$ : Hydrocele of a femoral hernia in a young woman. S Afr J Surg 2010;48:39.

23 Mote DG, Chakravarty KB: Hydrocoele of a femoral hernia sac. Hernia 2009;13:657-658.

24 Salama N, Blgozah S: Immediate development of post-varicocelectomy hydrocele: a case report and review of the literature. J Med Case Rep 2014;8:70.

25 Ein SH, Nasr A, Wales P, Gerstle T: The very large recurrent postoperative scrotal hydrocele after pediatric inguinal hernia repair: a rare problem. Pediatr Surg Int 2009;25:239241.

26 Davies BW, Fraser N, Najmaldin AS, Squire BR, Crabbe DC, Stringer MD: A prospective study of neonatal inguinal herniotomy: the problem of the postoperative hydrocele. Pediatr Surg Int 2003;19:68-70.

27 Lao OB, Fitzgibbons RJ Jr, Cusick RA: Pediatric inguinal hernias, hydroceles, and undescended testicles. Surg Clin North Am 2012; 92:487-504.

28 Obney N: Hydroceles of the testicle complicating inguinal hernias. Can Med Assoc J 1956;75:733-736.

29 Ward JF, Moquin RR, Maurer ST: Expanding the differential diagnosis of the acute scrotum: ventriculoperitoneal shunt herniation. Urology 2001;58:281.

30 Ozveren MF, Kazez A, Cetin H, Ziyal IM: Migration of the abdominal catheter of a ventriculoperitoneal shunt into the scrotum--case report. Neurol Med Chir (Tokyo) 1999;39: 313-315.

31 Ammar A, Ibrahim AW, Nasser M, Rashid M: CSF hydrocele--unusual complication of V-P shunt. Neurosurg Rev 1991;14:141-143.

32 Beiko DT, Watterson JD, Cook AJ, Denstedt JD: Group A streptococcal hydrocele infection and sepsis in a renal transplant recipient. Can J Urol 2003; 10:1768-1769.

33 Nellans RE, Ravera J: Seminoma in a renal transplant recipient. J Urol 1975;113:871873.

34 Simaioforidis V, Kontos S, Fokitis I, Lefakis G, Koritsiadis S: Subcutaneous emphysema of the scrotum (pneumoscrotum) due to traumatic pneumothorax: a case report. Cases J 2008;1:293
35 Trickett R, Dowd H: Angiokeratoma of the scrotum: a case of scrotal bleeding. Emerg Med J 2006;23:e57.

36 Koumanidou C, Manopoulou E, Pantazis J, Dermentzoglou V, Georgoulis P, Vakaki M, Kakavakis K: Scrotal hematocele as an unusual presentation of blunt abdominal trauma in three male infants. J Clin Ultrasound 2000; 28:190-193.

37 Chaudhary S, Bhullar JS, Subhas G, Mittal VK: Hematocele after laparoscopic appendectomy. JSLS 2012;16:660-662.

38 Lundy J, Hiles J, Paquette E: Bile causing an acute scrotum immediately after laparoscopic cholecystectomy. JSLS 2006;10:379-380.

39 Cuervo JL, Ibarra H, Molina M: Abdominoscrotal hydrocele: its particular characteristics. J Pediatr Surg 2009;44:1766-1770.

40 Sarwar U, Akhtar N: Fournier's gangrene developing secondary to infected hydrocele: a unique clinical scenario. Urol Ann 2012;4: 131-134.

41 Bruner DI, Ventura EL, Devlin JJ: Scrotal pyocele: Uncommon urologic emergency. J Emerg Trauma Shock 2012;5:206.

42 Kapoor AK, Puri SK, Arora A, Upreti L, Puri AS: Case report: Filariasis presenting as an intra-abdominal cyst. Indian J Radiol Imaging 2011;21:18-20.

43 Risaliti A, Corno V, Donini A, Cautero N, Baccarani U, Pasqualucci A, Terrosu G, Cedolini C, Bresadola F: Laparoscopic treatment of symptomatic lymphoceles after kidney transplantation. Surg Endosc 2000:14:293295.

44 Weinberg EJ, DuCret RP, Foshager MC, Berman J, Bodeau GR, Kuni CC, Boudreau RJ: Scrotal urinoma as a complication of renal transplantation. Clin Nucl Med 1994;19:749_ 750

45 Ataus S, Yaycioglu O, Onder AU, Onal B, Solok V: Giant spontaneous urinoma draining from the scrotal wall. J Urol 2000;163:18741875.

46 Firman R, Heiselman D, Lloyd T, Mardesich P: Pneumoscrotum. Ann Emerg Med 1993; 22:1353-1356

47 Kizer JR, Bellah RD, Schnaufer L, Canning DA: Meconium hydrocele in a female newborn: an unusual cause of a labial mass. J Urol 1995;153:188-190.

48 Aydin GB, Ciftçi AO, Yalçin B, Akçören Z, Ca lar M, Senocak ME, Büyükpamukçu M: Paratesticular metastasis from Wilms tumor associated with a hydrocele. Pediatr Blood Cancer 2006;47:97-99.

49 Llarena Ibarguren R, Zabala Egurrola JA, Arruza Echebarria A, Moratalla Basante A, Marín Lafuente JC, Lozano Ortega JL, Sanromá Ortueta I, Acha Pérez M, Albisu Tristán A, Blasco Villalonga M: Cytology positive for malignant cells in hydrocele secondary to testicular seminoma. Arch Esp Urol 1994;47: 71-72. 
50 Golebiewski A, Krolak M, Komasara L, Czauderna P: Dye-assisted lymph vessels sparing laparoscopic varicocelectomy. J Laparoendosc Adv Surg Tech A 2007;17:360-363.

51 Wallace AF: Aetiology of the idiopathic hydrocele. Br J Urol 1960;32:79-96.

52 Hattori M, Tonooka A, Zaitsu M, Mikami K, Suzue-Yanagisawa A, Uekusa T, Takeuchi T: Overexpression of aquaporin 1 in the tunica vaginalis may contribute to adult-onset primary hydrocele testis. Adv Urol 2014;2014: 202434.

53 Penn I, Mackie G, Halgrimson CG, Starzl TE: Testicular complications following renal transplantation. Ann Surg 1972;176:697-699.

54 Ijaz S: Rheumatoid hydrocele. J R Soc Med 2003;96:239-240.

55 Waldbaum RS, Green JL: Infected hydrocele. Cause of acute scrotal pain. Urology 1973;2: 73-74.

56 Wani I, Rather M, Naikoo G, Gul I, Bhat Z, Baba A: Encysted hydrocele of cord in an adult misdiagnosed as irreducible hernia: a case report. Oman Med J 2009;24:218-219.

57 Matsumoto A, Nagatomi Y, Sakai M, Oshi M: Torsion of the hernia sac within a hydrocele of the scrotum in a child. Int J Urol 2004;11: 789-791.

58 Traubici J, Daneman A, Navarro O, Mohanta A, Garcia C: Original report. Testicular torsion in neonates and infants: sonographic features in 30 patients. AJR Am J Roentgenol 2003;180:1143-1145.

59 Ilbey YO, Ozbek E, Simsek A: Torsion of testis with large epididymal cyst in a 57-year-old man: a case report. Arch Ital Urol Androl 2008;80:111-112.

60 Wilhelm E: The wandering testicular pain. Eur Urol 1977;3:76-77.

61 Nazir SS, Khan M: Thrombosis of the dorsal vein of the penis (Mondor's Disease): A case report and review of the literature. Indian J Urol 2010;26:431-433.

62 Dandapat MC, Padhi NC, Patra AP: Effect of hydrocele on testis and spermatogenesis. Br J Surg 1990:77:1293-1294.

63 Douglas JW, Hicks JA, Manners J, Hayes MC: A pressing diagnosis - a compromised testicle secondary to compartment syndrome. Ann R Coll Surg Engl 2008;90:W68.

64 Jung A, Schuppe HC: Influence of genital heat stress on semen quality in humans. Andrologia 2007;39:203-215.

65 Jung A, Strauss P, Lindner HJ, Schuppe HC: Influence of heating car seats on scrotal temperature. Fertil Steril 2008;90:335-339.

66 Hjollund NH, Storgaard L, Ernst E, Bonde JP, Olsen J: Impact of diurnal scrotal temperature on semen quality. Reprod Toxicol 2002; 16:215-221.

67 Zaslau S, Perlmutter AE, Farivar-Mohseni H, Chang WW, Kandzari SJ: Rhabdomyosarcoma of tunica vaginalis masquerading as hydrocele. Urology 2005;65:1001.
68 Jankovichova T, Jankovich M, Ondrus D, Kajo K, Dubravicky J, Breza J: Extremely rare tumour--malignant mesothelioma of tunica vaginalis testis. Bratisl Lek Listy 2015; 116:574-576.

69 Gyapong M, Gyapong J, Weiss M, Tanner M: The burden of hydrocele on men in Northern Ghana. Acta Trop 2000;77:287-

70294.

Waller JI, Hellwig CA: Cancer of the tunica vaginalis: review of literature and report of

71 one case. J Urol 1953;70:768-775.

Handa U, Bhutani A, Mohan H, Bawa AS: Role of fine needle aspiration cytology in nonneoplastic testicular and scrotal lesions and male infertility. Acta Cytol 2006;50:513-517.

72 Phillipou A, Castle D: Body dysmorphic disorder in men. Aust Fam Physician 2015;44: 798-801.

73 Cuervo Pinna C, Rodríguez Rincón JP, García-Moreno AA, Cabello Padial J, Murillo Mirat J, Fernández de Alarcón L: Spontaneous rupture of hydrocele: an unusual complication. Actas Urol Esp 1998;22:610-612.

74 Quint HJ, Miller JI, Drach GW: Rupture of a hydrocele: an unusual event. J Urol 1992; 147:1375-1377.

75 Payan HM, Mendoza C Jr, Ceraldi A: Diffuse leiomyomatous proliferation in the epididymis. A cause of pain in hydrocele. Arch Surg 1967;94:427-429.

76 Jones WG, Deeths HJ: Infected hydrocele in neonate. Urology 1975;5:526-527.

77 Kim KK, Park HW: An unusual infected hydrocele--a case report. J Korean Med Sci 1995; 10:42-43.

78 Saez F, Descalzo MJ, Herrera B, Castillo E, Cantero JA, Marchal C, Machuca Santa Cruz FJ: Hematocele secondary to rupture of an abdominoscrotal hydrocele. Arch Esp Urol 2013;66:877-879.

79 Vahlensieck W, Hesse A: Calculi in hydrocele: incidence and results of infrared spectroscopy analysis. Korean J Urol 2010;51: 362-364.

80 Candura SM, Canto A, Amatu A, Gerardini M, Stella G, Mensi M, Poggi G: Malignant mesothelioma of the tunica vaginalis testis in a petrochemical worker exposed to asbestos. Anticancer Res 2008;28:1365-1368.

81 Lantsberg L, Mor I, Levy I, Khoda J: Infected hydrocele following laparoscopic appendectomy: case report. Surg Laparosc Endosc 1997:7:262.

82 Yarram SG, Dipietro MA, Graziano K, Mychaliska GB, Strouse PJ: Bilateral giant abdominoscrotal hydroceles complicated by appendicitis. Pediatr Radiol 2005;35:12671270.

83 Wright LA, Gerscovich EO, Corwin MT, Lynch L, Lamba R: Tension hydrocele: additional cause of ischemia of the testis. J Ultrasound Med 2012;31:2041-2043.
84 Irfan M, Waldron R, Bolger J, Barry K: Transillumination: shining a light from within. BMJ Case Rep 2014;2014.

85 Hayden GE, Sprouse KL: Bowel obstruction and hernia. Emerg Med Clin North Am 2011; 29:319-345.

86 Chandanwale SS, Vimal SS, Rajpal M, Mishra N: A unique case of diffuse histiocytic proliferations mimicking metastatic clear cell carcinoma in the hydrocele sac. J Lab Physicians 2014;6:43-45.

87 Hussein O, El Setouhy M, Ahmed ES, Kandil AM, Ramzy RM, Helmy H, Weil GJ: Duplex Doppler sonographic assessment of the effects of diethylcarbamazine and albendazole therapy on adult filarial worms and adjacent host tissues in Bancroftian filariasis. Am J Trop Med Hyg 2004;71:471-477.

88 Huang SS, Wu DL, Gui YP, Zhao X, Xie $\mathrm{H}$ : Diagnosis and treatment of yolk sac tumor of the testis with hydrocele in children: report of 7 cases. Zhonghua Nan Ke Xue 2013;19: 1007-1010.

89 Massaro G, Sglavo G, Cavallaro A, Pastore G, Nappi C, Di Carlo C: Ultrasound prenatal diagnosis of inguinal scrotal hernia and contralateral hydrocele. Case Rep Obstet Gynecol 2013;2013:764579.

90 D'Andrea A, Coppolino F, Cesarano E, Russo A, Cappabianca S, Genovese EA, Fonio P, Macarini L: US in the assessment of acute scrotum. Crit Ultrasound J 2013;5(Suppl 1):S8.

91 Parelkar SV, Oak S, Bachani MK, Sanghvi B, Prakash A, Patil R, Sahoo S, Patel $\mathrm{J}$ : Laparoscopic repair of pediatric inguinal hernia--is vascularity of the testis at risk? A study of 125 testes. J Pediatr Surg 2011;46:1813-1816.

92 Rizvi SA, Ahmad I, Siddiqui MA, Zaheer S, Ahmad K: Role of color Doppler ultrasonography in evaluation of scrotal swellings: pattern of disease in 120 patients with review of literature. Urol J 2011;8:60-65.

93 Walker MR, Ernest AJ Jr, McMann LP: Hydrocele: an atypical presentation of metastatic sarcomatoid renal cell carcinoma. Can J Urol 2011;18:5742-5744.

94 Muglia V, Tucci S Jr, Elias J Jr, Trad CS, Bilbey J, Cooperberg PL: Magnetic resonance imaging of scrotal diseases: when it makes the difference. Urology 2002;59: 419-423.

95 Amodeo A, Liguori G, Trombetta C, Calgaro A, Patel HR, Belgrano E: A giant heterogeneous abdominoscrotal mass: haemorrhagic hydrocele. J Radiol Case Rep 2009; 3:16-20.

96 Zaitsu M, Mikami K, Takeshima Y, Takeuchi T: A case of hydrocele stone with its composition analysis. Case Rep Med 2010;2010:586204.

97 Parlaktas BS, Uluocak N, Filiz E, Erdemir F, Ozyurt H: Intrascrotal calculi: a very rare stone disease. Int J Urol 2006;13:849-850. 
98 Cassidy FH, Ishioka KM, McMahon CJ, Chu P, Sakamoto K, Lee KS, Aganovic L: MR imaging of scrotal tumors and pseudotumors. Radiographics 2010;30:665-683.

99 Marshall C, Markiewicz D, Bewley A: Adolescent "saxophone penis" secondary to Crohn's disease: misdiagnosed as being posttraumatic. Pediatr Dermatol 2016;33: e14-15.

100 Agrawal R, Chaurasia D, Jain M: Webbed penis: a rare case. Kathmandu Univ Med J (KUMJ) 2010;8:95-96.

101 Akgun C: A case of scrotal swelling mimicking testicular torsion preceding HenochSchonlein vasculitis. Bratisl Lek Listy 2012;113:382-383.

102 DaJusta DG, Granberg CF, Villanueva C, Baker LA: Contemporary review of testicular torsion: new concepts, emerging technologies and potential therapeutics. J Pediatr Urol 2013;9(6 Pt A):723-730.

103 Moon KH, Cho SJ, Kim KS, Park S, Park S: Recurrent varicoceles: causes and treatment using angiography and magnification assisted subinguinal varicocelectomy. Yonsei Med J 2012;53:723-728.

104 Bryan NP, Jackson A, Raftery AT: Carcinoma of the sigmoid colon presenting as a scrotal swelling. Postgrad Med J 1997;73: 47-48.

105 Baskin LS: Case no. 1. Newborn scrotal swelling and testicular mass. Tech Urol 2000;6:53-54.

106 Schuppe HC, Meinhardt A, Allam JP, Bergmann M, Weidner W, Haidl G: Chronic orchitis: a neglected cause of male infertility? Andrologia 2008;40:84-91.

107 Adeniyi M, Wiggins B, Sun Y, Servilla KS, Hartshorne MF, Tzamaloukas AH: Scrotal edema secondary to fluid imbalance in patients on continuous peritoneal dialysis. Adv Perit Dial 2009;25:68-71.
108 Sabar R, Safadi W: Relieving the burden: palliative centesis of an oedematous scrotal wall due to anasarca in end-stage heart failure. BMJ Case Rep 2013;2013.

109 Garrett JE, Cartwright PC, Snow BW, Coffin CM: Cystic testicular lesions in the pediatric population. J Urol 2000;163:928-936.

110 Lund L, Kloster A, Cao T: The long-term efficacy of hydrocele treatment with aspiration and sclerotherapy with polidocanol compared to placebo: a prospective, double-blind, randomized study. J Urol 2014; 191:1347-1350.

111 Francis JJ, Levine LA: Aspiration and sclerotherapy: a nonsurgical treatment option for hydroceles. J Urol 2013;189:17251729.

112 Dahl BH: Partial gangrene of the scrotum and penis. A complication of sclerotherapy of testicular hydrocele. Tidsskr Nor Laegeforen 1993;113:1232.

113 Jahnson S, Sandblom D, Holmang S: A randomized trial comparing 2 doses of polidocanol sclerotherapy for hydrocele or spermatocele. J Urol 2011;186:1319-1323.

114 Ozkan S, Bircan K, Ozen H: Treatment of testicular hydrocele with tetracycline sclerotherapy. Int Urol Nephrol 1990;22:67-69.

115 Miskowiak J, Christensen AB: Treatment of hydrocele testis by injection of tetracycline. Eur Urol 1988;14:440-441.

116 Yamamoto M, Hibi H, Miyake K: A new sclerosant therapy for testicular hydrocele with aspiration and injection of OK-432. Int Urol Nephrol 1994;26:205-208.

117 Shan CJ, Lucon AM, Arap S: Comparative study of sclerotherapy with phenol and surgical treatment for hydrocele. J Urol 2003; 169:1056-1059.

118 Roosen JU, Larsen T, Iversen E, Berg JB: A comparison of aspiration, antazoline sclerotherapy and surgery in the treatment of hydrocele. Br J Urol 1991;68:404-406.
119 Rencken RK, Bornman MS, Reif S: Multilocular hydrocele after sclerotherapy. Br J Urol 1988;62:92-93.

120 Garriga V, Serrano A, Marin A, Medrano S, Roson N, Pruna X: US of the tunica vaginalis testis: anatomic relationships and pathologic conditions. Radiographics 2009; 29:2017-2032.

121 Ding X: Sclerotherapy with tetracycline for hydrocele of the tunica vaginalis testis. $\mathrm{Br} \mathrm{J}$ Urol 1989;64:322.

122 Worthington-Kirsch RL: Injection sclerotherapy. Semin Intervent Radiol 2005;22: 209-217.

123 Dellis AE, Skolarikos A, Vavasis P, Spyropoulos E, Kalentzos VN: Spontaneous hydrocele resolution after hyperbaric oxygen treatment: a clinical case report. Undersea Hyperb Med 2010;37:199-201.

124 Cimador M, Castagnetti M, De Grazia E Management of hydrocele in adolescent patients. Nat Rev Urol 2010;7:379-385.

125 Bin Y, Yong-Bao W, Zhuo Y, Jin-Rui Y: Minimal hydrocelectomy with the aid of scrotoscope: a ten-year experience. Int Braz J Urol 2014;40:384-389.

126 Saber A: New minimally access hydrocelectomy. Urology 2011;77:487-490.

127 Al-Ali BM, Popper H, Pummer K: A case of Fournier's gangrene after hydrocelectomy. Cent European J Urol 2012;65:92-93.

128 Nicolson JW: Treatment of hydrocele by injection. Br Med J 1947;2:188.

129 Sirpa A, Martti AO: Results of fibrin glue application therapy in testicular hydrocele. Eur Urol 1998;33:497-499.

130 Koski ME, Makari JH, Adams MC, Thomas JC, Clark PE, Pope JC 4th, Brock JW 3rd: Infant communicating hydroceles--do they need immediate repair or might some clinically resolve? J Pediatr Surg 2010;45:590_ 593. 